\title{
Study of Female Image Interpretation under Harriet Beecher Stowe
}

\author{
Yan $\mathrm{Li}^{1}$ \\ ${ }^{1}$ Luohe Medical College, Luohe, Henan, 462000 \\ a email
}

Keywords: Mrs. Stowe; Female Image; Love; Fight

\begin{abstract}
Harriet Beecher Stowe Do not cut more than Ming Situo, is a world-renowned famous American female writer whose works on behalf of "Uncle Tom's Cabin" in one fell swoop established her place in the world literature. As a great woman writer, Mrs. Stowe that time women's living situation also showed a high degree of attention, which in 1871 published the essay "My wife and I," in a clearly explain their strong feminist stance , female characters described by its distinctive and diverse character, so the overall look more plump and perspective, this article will take this as a starting point, try to analyze the female image Stowe Works.
\end{abstract}

\section{Introduction}

Harriet Beecher Stowe (Harriet Beecher Stowe, 1811-1896) Do Ming Situo lady, she is a world-renowned famous American female writer whose works on behalf of "Uncle Tom's Cabin" in one fell swoop laid her in the world. literary status, while this anti-slavery novel historical process of American society also had a profound impact on literary and historical significance of its own with is beyond doubt. In addition to the "Uncle Tom's Cabin," Stowe major works there, "Dred, large, dark moor story," "Pearl of Orr's Island," "The old people of the town" and "palm fronds" Wait. Stowe was born in 1811 in Connecticut, USA Richfield County, a family pastor, their childhood and nurtured by the influence of Christianity, as well as issues concerning the abolition of slavery is the central theme of Stowe life times with a time when many advanced writers as Mrs. Stowe did not hesitate to choose the system abolitionist stand side, with his sensitive and firm strokes to reveal to the people the cruelty of slavery and darkness, and campaigned for the emancipation movement. Stowe attitude towards slavery inspired generations on behalf of self-power and continue to struggle with the black movement, so she is not only a symbol of American literature, but also a sign of the times. As a great woman writer, Mrs. Stowe that time women's living situation also showed a high degree of concern, especially for black women showed infinite compassion and mercy, which published the paper in 1871, "My wife and I "in a clearly explain his firm feminist stance, which also has some of the arguments feminists use of female characters described by its distinctive and diverse character, so the overall look more plump and perspective, this article will as a starting point, try to analyze the Stowe described the image of women.

\section{The Image of A White Woman under Mrs. Stowe Works}

Both on behalf of Mrs. Stowe American abolitionist literature, but also on behalf of the earliest feminist writers, thus rendering its relentless darkness of slavery, but also to a large audience shows a group of women in the lives of vulnerable white image of their lives has essentially similar between the situation and blacks are the victims and was the victim of society.

First, the kind of beautiful female image. Stowe is a devout Christian, so the majority of women have a pen of a kind, compassionate heart, but also has a very high moral quality, always with the hope that religious love and kindness dip, sentiment around everyone, but this beautiful and kind and did not change their status from the property. Novel "Uncle Tom's Cabin" was a kind-hearted wife Xie Erbei beautiful and noble character having an ordinary woman, she has always used his benevolence treat everyone around him, even the home of black slaves, her there is no racial bias in the minds of backward thinking, but ethnic, equality, freedom, and other advanced thought, when 
she knew her husband to sell black slaves Tom and Harry, she demonstrated strong ashamed of the heart, its deep inside Agency is not actually agree with her husband's practice, when Eliza fled with his son Harry after she did not show any dissatisfaction may complain, but do their best to help them. From this series of things that can be found in Xie Erbei wife does have noble character and moral principles, but her character being submissive there are defects, she's such a compromise and so weak in front of her husband she did not have any right to speak, although her husband did not agree to sell two slaves, but she has not been decided against her husband, she persuaded her husband and can not be changed slaves miserable living conditions in nature, but also can not emancipation movement in fact impact, but grew up in Mrs. Xie Erbei deepest love and kindness allows the reader to see hope for the future life. Secondly, selfish false image of women. Mrs. Stowe's pen in addition to the good, benevolent image of white women, but also create a lot of selfish and hypocritical image of white women, and they had a profound criticism and condemnation, but also gives a sympathetic attitude. "Uncle Tom's Cabin" Mary was a farmer's daughter, arrogant, fragile, selfish, brutal is her natural disposition, she did not like his wife or his wife Xie Erbei Patrizi was as gentle love kindness, she not only mind narrow, selfish and hypocritical, and even from his daughter did not do to the corresponding responsibility. You can see the novel by Mary's daughter Eva is a very caring little girl, because Uncle Tom's help, she will urge her father buy Uncle Tom, Tom later became a driver of their home, Eva uncle Tom and all together, this little girl's mind five or six a day does not exist any concept of race or class, she always used an angel to touch the hearts of people around, but then black and Mary has a strong contempt and prejudice in the hearts of Mary and black slaves is the "hypocrisy", "selfish", "ungrateful", so she can not really appreciate the real pain of its servants Ma Mi heart. In contrast, the formation of this character Mary has its inevitable reasons, although her husband gave her honest rich material life, but did not give her a happy married life, lonely inner world only with complaints, selfish like catharsis, and ultimately makes Mary into a selfish, hypocritical and ignorant image of women.

\section{Mrs. Stowe Two Black Women Image Writings}

In addition to the image of white women, Stowe also with their depiction of the many vivid images of black women, black women the image of the pen full of vitality and raw uncompromising put antipsychotic, which is actually Stowe a kind of women's own power praise. First, the female image ongoing revolt. With other abolitionist literature represent different black pen image Stowe always virtuous and full of revolt, which conveys the essence of black slaves Stowe inner sympathy and praise. In the "Uncle Tom's Cabin", the reader can see two black women continue to be the image of resistance --- Casey and Emmeline, who are both being sold to Uncle Tom met when the door • Le Geli , which has two black women continue to resist on the road to freedom and progress, although they are often being sold to sell to, but they did not lose the future and yearning for freedom. Casey is not only a tragic fate of black women, and she is a mother, Casey had to be separated from their children in the process of being auctioned, so she often endured the pain, inability to bear their own again children with their separation, she personally killed his children, so the plot is designed to allow readers to feel slavery was cruel and merciless, Casey actually practice this system complaints and revolt, it also awakened many black slaves still in a state of paralysis, aroused their enthusiasm against slavery and fight on the side, painstakingly efforts, Casey also found his long-lost daughter - - Eliza, eventually Emmeline, Eliza and so came to a country that can accommodate black --- Liberia, where years ago, Casey also found to be auctioned son. As can be seen, it is because of the continuous struggle against slavery and the system, they will be able to find their own country with his family at the end.

Secondly, having a female image of the original vitality. "Uncle Tom's Cabin" Topsy is a black girl with strong vitality of the original, she did not know exactly where they come from, who their parents are, but she did not admit that they have parents, she was neither parents create It is also not God's creation, she created her, so she is not subject to anyone's discipline and restraint. In short, Topsy is a straightforward naive, but smart wild unruly black girl. In the novel's outset, Topsy in a capricious and rogue image appears in front of the reader, this wild and willful though heartfelt, but 
Rexia a lot of trouble in life. When Topsy met Eva, Eva, who felt she gradually brought some kind of sincere affection, and was impressed by such feelings, she gradually learned proper manners and rules at this time Top West has degenerated into another black girl, but remain in their inner goodness and sincerity and without any changes. Stowe pen Topsy is actually a type of character, she is the representative of the whole world women primitive vitality in nature. In theory Stowe self, men are a direct manufacturer of slavery, is that they have this sense of community into a slave society, men can not be self-correcting itself, so all of this can only be completed by the last Women Women own existence is to correct the original vitality of all this power roots.

\section{Mother Female Characters under Mrs. Stowe}

Most Stowe pen works have shown a struggling black slaves, but also entangled in this conflict depicts the image of many mothers can say that slavery exists in nature but it reinforces women species maternal image, and the image of the mother through the pain cries conveys the author himself to abolish slavery attitude and determination.

First, the brave and intelligent mother image. Stowe hopes to portray the image of the mother shows women themselves bears force, hoping to wake up the American people's minds the only love and compassion through this power. Eliza was "Uncle Tom's Cabin" in a very distinctive character of the image of the mother, when she heard Mr. Xie Erbei to sell his son inadvertently, she did not hesitate with his son he decided to flee Iraq Lisa know the consequences son was sold later, she hopes his son Harry to have their own free sky, and while she did not want their children to be separated forever, it is this natural maternal love so she gave up on the master loyalty. In the process of escape, Eliza showed a woman of wit and intelligence, when they encountered the police, she did not choose and Harry escape, but escape from police questioning in calm and yet in deportment and tracing, when she saw Lady Bird when it inferred by mourning Byrd lost their children, which actually gained the trust and sympathy of Mrs. Bird, Lady Bird thereby helping to lower fled safe place. In the course of their flight, not only showed Eliza intelligent smart women, while women also showed their own unique strong and brave, she overcame hardships along the way, from the US to Canada, then to France, eventually settled in Liberia. It can be seen, Eliza's actions proved to readers female great maternal love, on the contrary, their maternal glory but also achievements in the great mother image.

Second, caring loving mother of Christ image. If Eliza's mother is brave and intelligent image, then Xie Erbei wife and Lady Bird are caring loving mother image. Both of them are devout Christians, so caring and so noble character is always buried deep in their hearts. Xie Erbei wife always in a religious conduct educate their children, George, so readers can see George and his father has a fundamentally different, George not only warm hearted, and also special attention to the friendship between Uncle Tom he and his wife Xie Erbei same mind does not exist any discrimination and prejudice, and under her mother's influence, George always with a grateful heart to treat around the black slaves, and finally all his house Negro slaves were freed, we can see that everything George did actually follow the teachings of his mother, the mother of Christ Mrs. Xie Erbei image becomes increasingly distinct prominent. Lady Bird and his wife Xie Erbei as always with a heart of caring kind heart when she saw Eliza fleeing mother, she did not hesitate to extend to them a helping hand, because she remembered his son Henry, she is always with Christian love and love to educate Henry, but Henry's death did not change the initial MRS.BIRD heart, she has always been convinced of the noble and precious life, so Lady Bird miss his son's painful process Eliza still help, but give her this charity action has deeply touched the little Harry, let him to life, love, etc. have a deeper understanding, and this spirit will continue to be passed along.

In summary, from Stowe depiction of women, you can see she was an early feminist, but also can see her on the slavery of hate and disgust. She has always been concerned about the situation of blacks living with a heart of compassion and cry constantly call and then from my desire to convey to building a better society. 


\section{References}

[1] Liu Dan: "Analysis <Uncle Tom's Cabin> Mother image", "Inner Mongolia University for Nationalities" (Social Science Edition), 2013 (1).

[2] Gu Chenjuan: "' Uncle Tom's Cabin> in white female image "," Consumer Guide ", 20086.

[3] Chen Ting: "On <Uncle Tom's Cabin> embodied female messianism," "Legend • Biographies election issue" (theory), 20112. 